\title{
INTERNET OF THINGS (IOT) IN WATER QUALITY MONITORING SYSTEMS AND NUTRITION IN HYDROPONIC PLANTS
}

\author{
Irawati, Diar Irmawati, M. Ganda Arya Permana and Mohamad Riziq Amri \\ Swadharma Institute of Technology and Business \\ E-mail: irawati2182@gmail.com, diarirmawati@gmail.com, \\ gans.indonesian6@gmail.com dan mohamadriziq10@gmail.com
}

\begin{tabular}{|c|c|}
\hline ARTICLE INFO & ABSTRACT \\
\hline $\begin{array}{l}\text { Received: } \\
\text { July, 24th } 2021 \\
\text { Revised: } \\
\text { August, 9th } 2021 \\
\text { Approved: } \\
\text { August, } 13^{\text {th }} 2021\end{array}$ & $\begin{array}{l}\text { Abstract Population is growing every year. This has an impact } \\
\text { on the reduction of agricultural land to cultivate crops. This } \\
\text { study aims to combine a concept that aims to expand the } \\
\text { benefits of continuously connected internet connectivity. } \\
\text { Based on the long term, the narrowing of agricultural land } \\
\text { will have an impact on the scarcity of hydroponic NFT } \\
\text { (Nutrient Film Technique) is a model of cultivation by putting } \\
\text { the roots of plants in a shallow layer of water. The water is } \\
\text { circulated and contains nutrients according to the needs of } \\
\text { plants. This study combines hydroponic plants with the help } \\
\text { of Internet of Things (loT) technology using hydroponic } \\
\text { planting techniques. Rooting can develop in a nutrient } \\
\text { solution, because around rooting there is a layer of nutrient } \\
\text { solution then the system is known as NFT. Excess water } \\
\text { reduces the amount of oxygen and dissolved nutrients. The } \\
\text { use of a manual measuring instrument is actually time- } \\
\text { consuming if the owner is busy. Based on this background, } \\
\text { the author got the idea to create a system of monitoring } \\
\text { water quality and nutrients in hydroponic plants that can be } \\
\text { accessed through a mobile phone. }\end{array}$ \\
\hline KEYWORDS & Hydroponic, Internet of Things, NFT \\
\hline (cc) (7) (? & $\begin{array}{l}\text { This work is licensed under a Creative Comr } \\
\text { Attribution-ShareAlike } 4.0 \text { International License }\end{array}$ \\
\hline
\end{tabular}

\begin{tabular}{ll}
\hline & Irawati, Diar Irmawati, M. Ganda Arya Permana and Mohamad Riziq Amri. \\
& (2021). Internet Of Things (lot) In Water Quality Monitoring Systems And \\
& Nutrition In Hydroponic Plants. Journal Eduvest. 1(8): 676-684 \\
How to cite: & $2775-3727$ \\
E-ISSN: & https://greenvest.co.id/
\end{tabular}




\section{INTRODUCTION}

The development of technology and science is growing very rapidly (Ngafifi, 2014). In almost all corners of the world, technology has become a necessity (Putra, 2017) that cannot be separated from everyday life (Artikasari \& Saefudin, 2017). All aspects of life are affected by these technological developments (Setiawan, 2018). Internet of things (IoT), is one of the technologies that are currently developing (Junaidi, 2015). According to IoT technology, all activities carried out by humans can be controlled through the internet network (Savitri, 2019).

Technological developments have also penetrated into the agricultural sector (Ariningsih, 2016). One example is the emergence of a hydroponic farming system due to the lack of agricultural land (Rahmi et al., 2020) due to land competition with the industrial sector (Mawardi, 2006). The definition of hydroponics itself is planting in water containing a mixture of nutrients (Lukmanul, 2020). Based on current practice, hydroponics cannot be separated from the use of other growing media (Sururuzzaman, Munadi, \& Irawan, 2020) that is not soil as a support for plant growth, one of which is the Hydroponic NFT (Nutrient Film Technique) method (Prayitno, Muttaqin, \& Syauqy, 2017). NFT is a cultivation model by placing plant roots in a shallow layer of water (Wibowo, 2019). The water is circulated and contains nutrients according to plant needs (Yulina, 2019). Roots can develop in a nutrient solution, because around the roots (Roidah, 2014) there is a layer of nutrient solution, the system is known as NFT (Rahmawati, 2021). Excess water will reduce the amount of dissolved oxygen and nutrients (Pardede, 2013).

The Internet of Things was first introduced by the British visionary Kevin Ashton, in 1999. The Internet of Things (IoT) is a collection of things (things), in the form of physical devices (hardware/embedded systems) capable of exchanging information between information sources, operators and operators. services or other devices that are connected to the system so that they can provide greater benefits. Physical devices (hardware/embedded system) in the infrastructure.

Internet of Things is embedded hardware with electronics, software, sensors and connectivity. Embedded system devices perform computing for data processing from sensor inputs and operate within the internet infrastructure. Internet of Things, also known as IoT, is a concept that aims to expand the benefits of continuously connected internet connectivity. As for capabilities such as data sharing, remote control and so on, including objects in the real world. For example, food, electronics, collectibles, any equipment, including living things, all of which are connected to local and global networks through embedded sensors and are always active. Some examples of Internet of Things applications are air temperature and humidity monitoring system projects on hydroponic plants, temperature regulation of indoor humidity and automatic watering on Android-based hydroponic lettuce plants, Android-based rice field water quality monitoring, and online water and soil quality monitoring online and offline in real time. 


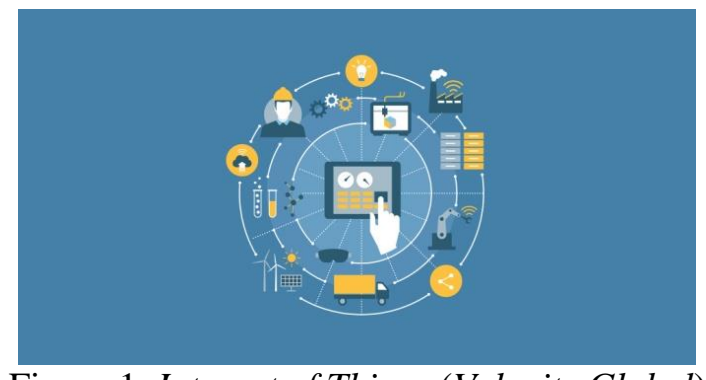

Figure 1. Internet of Things (Velocity Global)

NodeMCU is basically an extension of the ESP 8266 with e-Lua based firmware. The NodeMCU is equipped with a micro usb port that functions for programming and power supply. In addition, the NodeMCU is equipped with a push button, namely the reset and flash buttons. NodeMCU uses the Lua programming language which is a package from ESP8266. The Lua language has the same logic and programming structure as C, only the syntax is different. If you use Lua, you can use the Lua loader and Lua uploader tools. In addition to the Lua language, NodeMCU also supports Arduino IDE software by making a few changes to the Arduino IDE board manager. Before using this board, it must be flashed first so that it supports the tool that will be used. If using the Arduino IDE, use a suitable firmware, namely the firmware output from AiThinker which supports AT Command. For the use of the Firmware loader tool, the NodeMCU firmware is used.

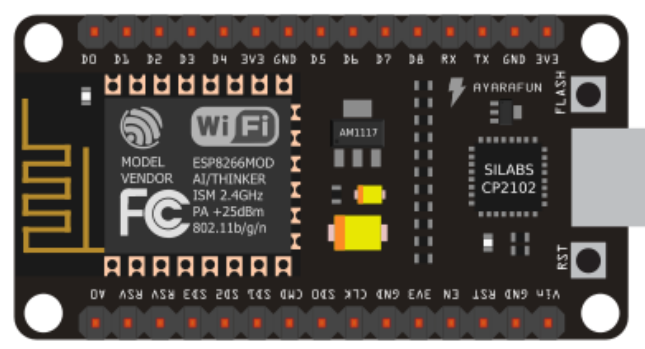

Figure 2. Node MCU ESP 8266 (Fritzing)

The DS18B20 temperature sensor is a temperature measuring device with waterproof capabilities. Suitable for measuring temperature in difficult or wet places. Because the data output of this device is digital data, it is very good when used for long distances, without having to worry about data degradation. The DS18B20 sensor provides 12 bits. Since each DS18B20 sensor has a unique silicon serial number, multiple DS18B20 sensors can be mounted in a single bus. This allows temperature readings from various places. Although the datasheet of this sensor can reads well up to $125^{\circ} \mathrm{C}$, but with a PVC cable cover it is recommended not to exceed $100^{\circ} \mathrm{C}$.

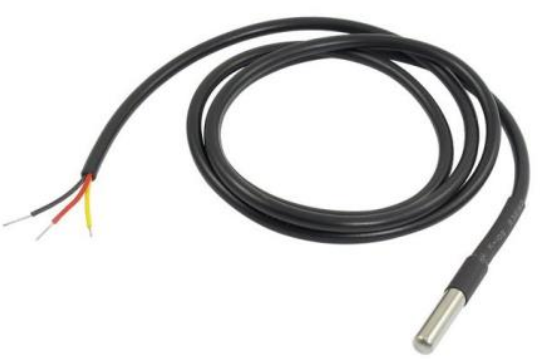


Irawati, Diar Irmawati, M. Ganda Arya Permana and Mohamad Riziq Amri

Figure 3. Probe DS18B20

TDS DFRobot is a sensor used to measure solid materials dissolved in water that are invisible to the eye, can be solid particles such as metal content such as iron, aluminum, copper, manganese and others, as well as non-solid particles such as microorganisms. This TDS is compatible with Arduino, Plug and Play. 


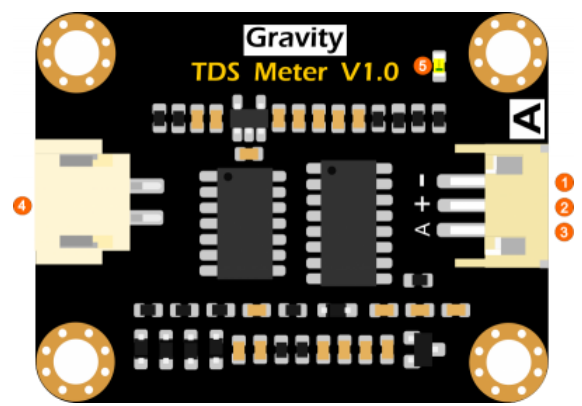

Figure 4. TDS Meter DFRobot

Jumper cables are electrical cables that function to connect between components on a breadboard or Arduino board without having to use solder. In general, jumper cables are equipped with pins at each end.

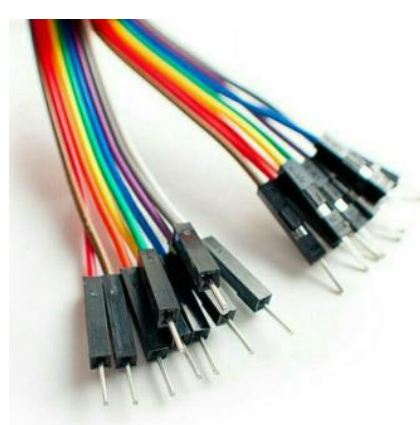

Figure 5. Kabel Jumper

In the NodeMCU, a MicroUSB type USB cable is used as a power connector and a data cable to send programs from the Arduino software to the NodeMCU Board

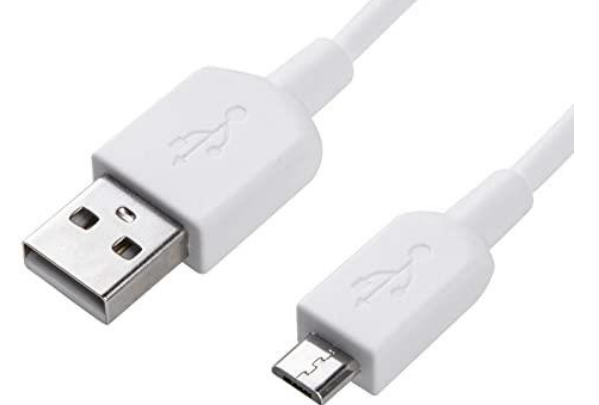

Figure 6. Micro USB

Arduino IDE (Integrated Development Environment) is software that has been prepared by Arduino for designers to carry out various processes related to Arduino programming. Arduino IDE also supports various popular operating systems today such as Windows, Mac and Linux (Ecadio, 2015). 


\section{Irawati, Diar Irmawati, M. Ganda Arya Permana and Mohamad Riziq Amri}

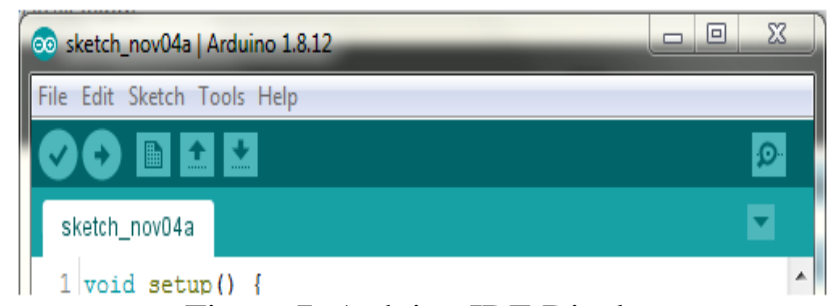

Figure 7. Arduino IDE Display

Blynk is an application platform that can be downloaded for free on iOS and Android users that can be used to control Arduino, NodeMCU, Raspberry Pi and the like via the Internet. This application is able to support Internet of Things projects because in this application it can be used to control hardware devices, display sensor data, store data, visualize and others.

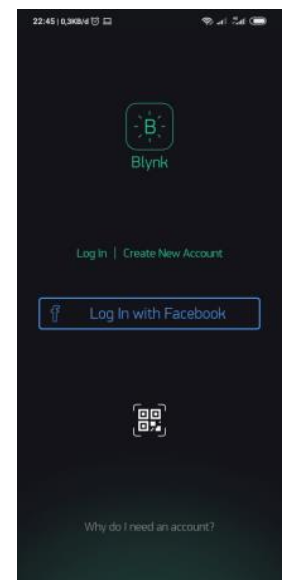

Figure 8. Blynk application

Fritzing App is an electronic design automation software with a low barrier of entry, suitable for the needs of both the maker and the hobbyist. It offers a unique real-life breadboard view, and a parts library with many of the most commonly used high-level components. This study aims to integrate a concept that aims to expand the benefits of continuously connected internet connectivity. The benefit of this research is to get the right solution in hydroponic system cultivation by utilizing IoT-based technology for the automatic monitoring of plants.

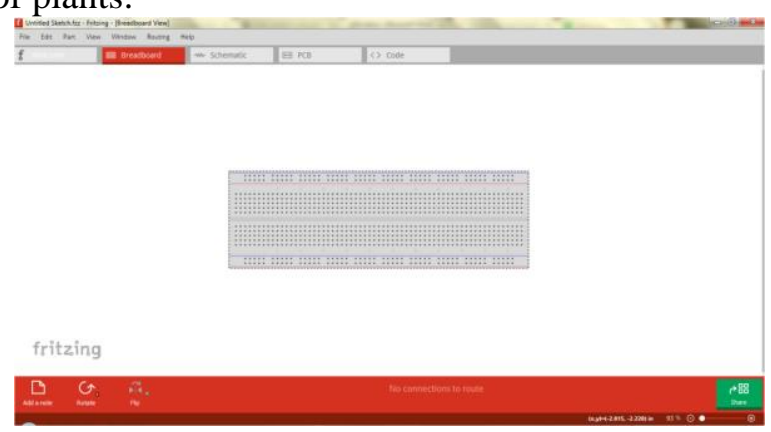

Figure 9. Fritzing

\section{RESEARCH METHODS}

This research method uses descriptive qualitative method by using literature 
study and related theoretical basis. Literature study was conducted to find reference materials to be used in this study. By searching for books, journals on priority selection or through the internet. Design Determining the Water Quality and Nutrition Monitoring system in Hydroponic Plants based on the Internet of Things consists of designing hardware and software.

This project monitoring approach is designed to function as a web page based monitoring system that exposes environmental situations via the ESP8266 module. Under this scope, the system can monitor and implement control measures in certain cases. The system is built from different sensors which are used to record the required data from the proposed location to analyze the environmental situation.

\section{RESULTS AND DISCUSSION}

\section{Hardware Design}

To realize Water Quality and Nutrition Monitoring on Internet of Things-based Hydroponic Plants, careful design is needed.

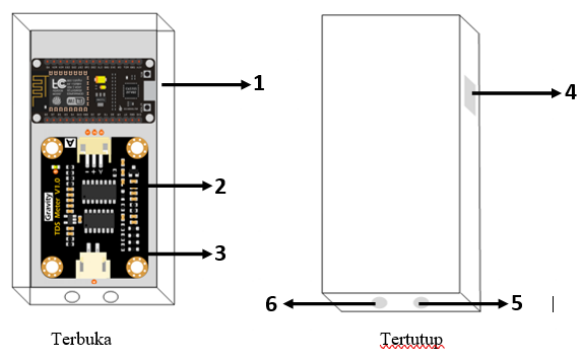

Figure 10. Open System Design

The description of the numbers in the image above is as follows:

1) NodeMCU

2) White box measuring $10 \times 7 \times 3$

3) TDS Meter

4) Micro USB Hole

5) DS18B20 . Probe Hole

6) TDS Meter Probe Hole

The following is a block diagram of the Internet of Things-based Water Quality and Nutrient Monitoring tool in Hydroponic Plants:

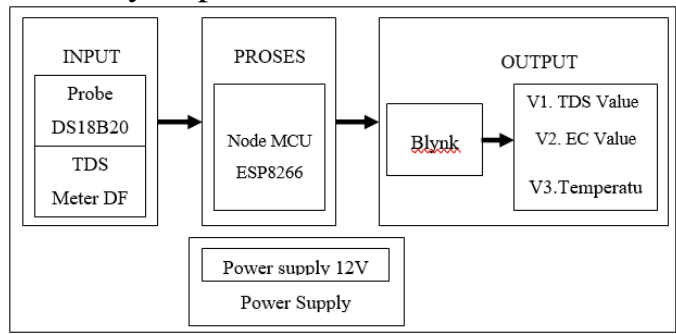

Figure 11. Block Circuit Diagram

a) Power Supply Block

The power supply block serves as the main voltage source as input to the NodeMCU microcontroller 
b) Input block

The input block consists of a DS18B20 probe which functions as a water temperature detector and a TDS meter which functions as a measure of water quality and dissolved nutrients.

c) Process Block

The process block is a major part of the water quality and nutrient monitoring tool for hydroponic plants based on the Internet of Things. The process block can also be called the brain of this series of tools and for its own components using the NodeMCU microcontroller.

d) Output Block

The output block is the final part of this circuit diagram. This output block itself contains a blynk application that functions to display data that has been processed by the NodeMCU, the output data are TDS Value, EC Value and Water temperature.

\section{Software Design}

Software design for Monitoring Water Quality and Nutrients in Hydroponic Plants based on Internet of Things consists of Arduino IDE, Blynk and Flowcart.

a) Arduino IDE

In this design, the programming tool used is the Arduino IDE software. Arduino IDE was chosen because this software is compatible with the NodeMCU board used in the design of the Water Quality and Nutrition Monitoring tool for Internet of Thingsbased Hydroponic Plants.

\section{b) Blynk (Internet of Things)}

The Blynk based control monitoring system is demonstrated as shown in the Figure below which shows the Blynk page with realized results. As previously mentioned the system can apply control actions even automatically or manually through the application.

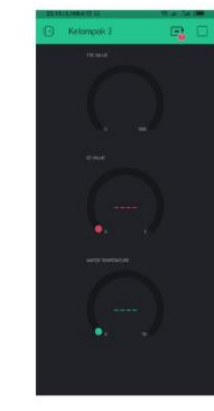

Figure 12. Sensor Detection

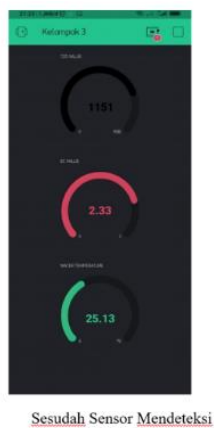

c) Flow chart

Due to the complexity of the program code, it was proposed to show the entire code as a simple flow chart shown in figure 13. First of all, it should be reminded that the analog reading range for a sensor connected to one of the analog pins on the Arduino is determined by $(0-1023)$. 


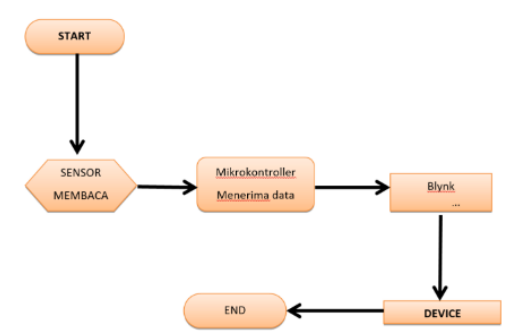

Figure 13. Sensor Working Flow

The TDS and DS18B20 sensors read the substances contained and at the same time the temperature in the water. Then the data obtained from the two sensors is sent to the NodeMCU microcontroller. Based on programming on the microcontroller requires an authentication code to connect to the Blynk IoT platform. On the Blynk platform, it acts as a server that displays data, so that data can be seen by clients, namely devices.

\section{CONCLUSION}

Based on the design of systems and devices for monitoring the quality of water and nutrients in hydroponic plants based on the Internet of Things, it can be concluded that this system can monitor the quality of water and nutrients in hydroponic plants according to user needs. The sensor used is working fine. The Blynk application and the NodeMCU microcontroller can communicate well. The Blynk app is very simple and easy to understand.

\section{REFERENCES}

Ariningsih, Ening. (2016). Prospek penerapan teknologi nano dalam pertanian dan pengolahan pangan di Indonesia. Forum Penelitian Agro Ekonomi, 34(1), 1-20.

Artikasari, Evaderika Ayu, \& Saefudin, Abdul Aziz. (2017). Menumbuh kembangkan kemampuan berpikir kreatif matematis dengan pendekatan contextual teaching and learning. Jurnal Math Educator Nusantara: Wahana Publikasi Karya Tulis Ilmiah Di Bidang Pendidikan Matematika, 3(2), 73-82.

Junaidi, Apri. (2015). Internet of things, sejarah, teknologi dan penerapannya. Jurnal Ilmiah Teknologi Infomasi Terapan, 1(3).

Lukmanul, Asep. (2020). Simulasi POACE pada budidaya pertanian dengan metode hidoponik (POACE Simulation in Agricultural Cultivation Using the Hydroponic Method). Available at SSRN 3617944.

Mawardi, Ikhwanuddin. (2006). Kajian pembentukan kelembagaan untuk pengendalian konversi dan pengembangan lahan, peran dan fungsinya. Jurnal Teknologi Lingkungan, 7(2).

Ngafifi, Muhamad. (2014). Kemajuan teknologi dan pola hidup manusia dalam perspektif sosial budaya. Jurnal Pembangunan Pendidikan: Fondasi Dan Aplikasi, 2(1).

Pardede, Erika. (2013). Tinjauan komposisi kimia buah dan sayur: peranan sebagai nutrisi dan kaitannya dengan teknologi pengawetan dan pengolahan. Jurnal Visi, 21(3).

Prayitno, Wahyu Adi, Muttaqin, Adharul, \& Syauqy, Dahnial. (2017). Sistem Monitoring Suhu, Kelembaban, dan Pengendali Penyiraman Tanaman Hidroponik menggunakan Blynk Android. Jurnal Pengembangan Teknologi Informasi Dan Ilmu Komputer E-ISSN, 2548, 964X.

Putra, Chandra Anugrah. (2017). Pemanfaatan Teknologi Gadget Sebagai Media Pembelajaran. Bitnet: Jurnal Pendidikan Teknologi Informasi, 2(2), 1-10. 


\section{Irawati, Diar Irmawati, M. Ganda Arya Permana and Mohamad Riziq Amri}

Rahmawati, Puput Ike. (2021). Sistem Hidroponik Sayuran Daun di Taman Botani Sukorambi. Jember: Politeknik Negeri Jember.

Rahmi, Devi Yulia, Faisal, Ranny Fitriana, Agestayani, Agestayani, Susiana, Susiana, Marlina, Winny Alna, Mardiah, Fatma Poni, Erizal, Erizal, Ahmad, Faisal Ali, \& Srivani, Musbatiq. (2020). Hidroponik sebagai bentuk pemanfaatan lahan sempit untuk peningkatan pendapatan rumah tangga di Nagari Sungai Kamuyang. Jurnal Hilirisasi IPTEKS, 3(1), 20-30.

Roidah, Ida Syamsu. (2014). Pemanfaatan lahan dengan menggunakan sistem hidroponik. Jurnal Bonorowo, 1(2), 43-49.

Savitri, Astrid. (2019). Revolusi Industri 4.0: Mengubah Tantangan Menjadi Peluang di Era Disrupsi 4.0. Yogyakarta: Penerbit Genesis.

Setiawan, Daryanto. (2018). Dampak perkembangan teknologi informasi dan komunikasi terhadap budaya. JURNAL SIMBOLIKA: Research and Learning in Communication Study, 4(1), 62-72.

Sururuzzaman, Muhammad Fuadi, Munadi, Rendy, \& Irawan, Arif Indra. (2020). Analisis Performansi Protokol MQTT Pada Sistem Kontrol Hidroponik Tanaman Pakcoy. eProceedings of Engineering, 7(3).

Wibowo, Agung Trilaksono. (2019). Teknik Budidaya Kailan (brasissica oleracea l.) Dengan Sistem Hidroponik NFT (nutrient film technique) Di PT. Agro Duasatu Gemilang Malang. Jember: Politeknik Negeri Jember.

Yulina, Henly. (2019). Penyuluhan Budidaya Tanaman Hidroponik di Desa Kalensari Kecamatan Widasari Kabupaten Indramayu. Abdi Wiralodra: Jurnal Pengabdian Kepada Masyarakat, 1(2), 112-124. 